\title{
MORPHOLOGY AND KINETICS OF PETROLEUM WAX DISSOLUTION IN HYDROCARBON SYSTEMS
}

\section{МОРФОЛОГИЯИКИНЕТИЧЕСКИЕПАРАМЕТРЫРАСТВОРЕНИЯНЕФТЯНЫХПАРАФИ НОВВРАЗЛИЧНЫХУГЛЕВОДОРОДНЫХСИСТЕМАХ}

\author{
IVANOVA, Izabella Karlovna ${ }^{1,2^{*}}$; DIAKONOV, Afanasii Alekseevich ${ }^{1}$; SEMENOV, Matthew \\ Egorovich $^{1,2}$; KORYAKINA, Vladilina Vladimirovna ${ }^{1}$ \\ ${ }^{1}$ Ammosov North-Eastern Federal University, 58 ul. Belinskogo, Yakutsk zip code 677000 Russia \\ ${ }^{2}$ Institute of Oil and Gas Problems of Siberian Branch of the Russian Academy of Sciences, 1 ul. Oktyabrskaya, \\ Yakutsk zip code677980 Russia \\ * Corresponding author \\ iva-izabella@yandex.ru
}

Received 06April 2018; received in revised form 14May 2018; accepted 15 May 2018

\section{RESUMO}

Este trabalho estuda o efeito da natureza química do solvente nos parâmetros cinéticos de dissolução e na morfologia das ceras de petróleo. A cinética da dissolução da cera de petróleo em condensado de gás e na mistura hexano-ciclo-hexano-benzeno foi examinada na balança de torção dentro da faixa de temperatura de 10 a $40^{\circ} \mathrm{C}$. O processo foi descrito usando a equação de Erofeev-Kolmogorov. Os seguintes parâmetros cinéticos foram calculados: taxa de reação, ordem de reações e energia efetiva para ativar a dissolução de cera nos solventes estudados. Verificou-se que a taxa de dissolução de cera no compósito ternário é uma ordem de magnitude maior e a energia de ativação é três vezes menor em comparação com o processo de dissolução de cera no condensado de gás. As características morfológicas das amostras de cera, tratadas por estes solventes, foram examinadas por meio de microscopia eletrônica de varredura. Verificou-se que no compósito ternário, a cera possui uma estrutura porosa e no condensado do gás é comprimida. Assim, o comportamento cinético e morfológico identificado das ceras de petróleo indica a influência da natureza química do solvente. Os achados deste estudo podem ser úteis na escolha do solvente para a remoção dos depósitos de parafina.

Palavras-chave: Parafina de petróleo, taxa de dissolução, modo cinético e de difusão, microscopia eletrônica de varredura, solventes de hidrocarbonetos.

\begin{abstract}
This paper studies the effect of solvent chemical nature on the kinetic parameters of dissolution and the morphology of the petroleum waxes. The kinetics of the petroleum wax dissolution in gas condensate and the hexane-cyclohexane-benzene mixture was examined on the torsion balance within the temperature range from 10 to $40^{\circ} \mathrm{C}$. The process was described using the Erofeev-Kolmogorov equation. The following kinetic parameters were calculated: reaction rate, the order of reactions and effective energy for activation the wax dissolution in the studied solvents. It was found that the wax dissolution rate in the ternary composite is an order of magnitude greater and the activation energy is three times less in comparison with the process of wax dissolution in the gas condensate. The morphological features of the wax samples, treated by these solvents, were examined by means of scanning electron microscopy. It was found that in the ternary composite, wax has a porous structure and in the gas condensate, it is compressed. Thus, the identified kinetic and morphological behavior of petroleum waxes indicates the influence of the chemical nature of the solvent. The findings of this study can be useful when choosing a solvent for the paraffin deposits removal.
\end{abstract}

Keywords: Petroleum paraffin, the rate of dissolution, kinetic and diffusion mode, scanning electron microscopy, hydrocarbon solvents 


\section{АННОТАЦИЯ}

Цель работы - исследование влияния химической природы растворителя на кинетические параметры растворения и морфологию нефтяных парафинов. Кинетика растворения нефтяных парафинов в газовом конденсате и гексан-циклогексан-бензольной смеси исследовалась на торсионных весах в интервале температур от 10 до $40^{\circ} \mathrm{C}$. Кинетическое описание процесса выполнено при помощи уравнения Ерофеева-Колмогорова. Рассчитаны кинетические параметры: константы скоростей, порядок реакций и эффрективная энергия активации растворения парафинов в исследуемых растворителях. Установлено, что скорость растворения парафинов в тройном композите на порядок выше, а энергия активации в три раза меньше, по сравнению с процессом растворения парафинов в газовом конденсате. Методом сканирующей электронной микроскопии изучены морфологические особенности обработанных этими растворителями образцов парафина. Установлено, что в тройном композите парафин имеет пористую структуру, а в газовом конденсате происходит его уплотнение. Таким образом, выявленные кинетические и морфологические особенности поведения нефтяных парафинов указывают на влияние химической природы растворителя, что позволяет осуществить целенаправленный выбор растворителя для удаления парафиновых отложений.

Ключевые слова: нефтяные парафины, порядок и константа скорости реакции, диффузионный и кинетический режим, алифратические, нафртеновые и ароматические углеводороды

\section{INTRODUCTION}

In the world's oil fields, the problem of asphaltene-resin-paraffin deposits (ARPD) is solved mainly by the thermal and chemical methods. However, systematic thermal treatment to remove ARPD in a large number of wells leads to considerable material costs. Therefore, the chemical methods are considered to be the most promising, universal and cost-effective. The essence of the chemical disposal techniques is in the preliminary destruction or dissolution followed by removal of the deposits. The methods of targeted selection and assessment of the ARPD solvent efficiency are rather well understood. The studies by Savinykh et al. (2007), Kamenshchikov (2008), Glushchenko et al. (2009), and Ibragimov et al. (2010) determined that the main criterion for choosing a solvent is the ARPD type. Depending on the components contained in ARPD in high concentrations, ARPD can be of paraffin, asphaltene and mixed type. Ragulin et al. (2001) showed the effective solvents for paraffin ARPD are low-boiling aliphatic hydrocarbons (HC) such as pentane, hexane, and heptanes. Khisamutdinov et al. (1990) proved that, for asphaltene ARPD removal, the solvents based on aromatic hydrocarbons should be used. However, using reagents, selected only on the basis of the ARPD type, does not always give positive results in the oilfields. This is because the reagents for paraffin deposits removal are assessed and selected without regard to the physical and chemical nature and the diversity of the intermolecular interactions of the multicomponent solvents with the high molecular weight compounds of oil; lack of information on the properties of reagents, included in solvent composition, also plays a role (Dolomatov et al., 1991, Kamenshchikov, 2008).

Thus, this paper aims to study the effect of solvent chemical nature on the kinetic parameters of dissolution and the morphology of the petroleum waxes. This work is a continuation of research on assessment and selection of the effective reagents for paraffin deposits (Ivanova et al., 2014, Ivanova et al., 2015). Previously, it was determined that the degree of petroleum wax crystallinity in various model solvents increases in the solvents series: aliphatic-naphthenic-aromatic $\rightarrow$ aliphatic-aromatic $\rightarrow$ aliphatic-naphthenic $\rightarrow$ aliphatic. It was also found that the temperature of the crystallization and melting of wax in the aliphatic and aliphatic-naphthenic-aromatic solvents is characterized by maximum values as compared to the aliphatic-aromatic systems.

\section{MATERIALS AND METHODS}

Since the ARPD in the Irelyakhskoe field (Yakutia, Russia) belong to paraffin type, the B2 petroleum wax (GOST 23683-89, 2007) was selected as the model of paraffin ARPD. This highly-purified paraffin contains no water or 
mechanical impurities that may distort the experimental results. The following was studied as solvents of paraffin: gas condensate of alkane base, which is currently used in the Irelyakhskoe field for removing ARPD deposits, and composite mixture, consisting of hexane, benzene and cyclohexane (HBCG) in ratios 1:1:1. The kinetics of paraffin dissolution in hexane and hexanebenzene mixture was examined by Ivanova (2014). The kinetics of paraffin dissolution in these $\mathrm{HC}$ was studied gravimetrically on the VLKT 500 torsion balance at temperatures 10 and $25^{\circ} \mathrm{C}$, which correspond to the seasonal operating conditions at the Irelyakhskoe field, and $40^{\circ} \mathrm{C}$ to determine the overall dependency of paraffin dissolution rate from temperature. The degree of dissolution ( $\alpha$ ) was calculated as the ratio of melted paraffin to its original total mass in the sample. The amount of solvent in the experiments was $70 \mathrm{~cm} 3$. The statistical calculation of the kinetic model parameters, expressed in linear form, was carried out by the least squares method using t-distribution with a confidence probability of 0.95 (Klinger, 1972). At least three tests of each sample were conducted.

In order to study the morphology of the samples in the pre-weighted weighing bottles, $10 \%$ paraffin solutions were prepared in the $\mathrm{HC}$ systems under study. The weighing bottles with the contents were brought to the permanent weight in the drying oven. The microphotographs of the samples were obtained by the JCM-7800F Jeol scanning electron microscope (Japan). The sample was secured on the two-sided conducting adhesive tape pasted to a metal substrate. The samples were studied by means of secondary electrons at a low accelerating voltage (a Schottky cathode), which provides a quality image without the conducting surface layer and helps to avoid distortion of the structure at a high magnification.

\section{RESULTS AND DISCUSSION:}

Figure 1 shows the kinetic curves of paraffin dissolution in $\mathrm{HC}$ solvents.

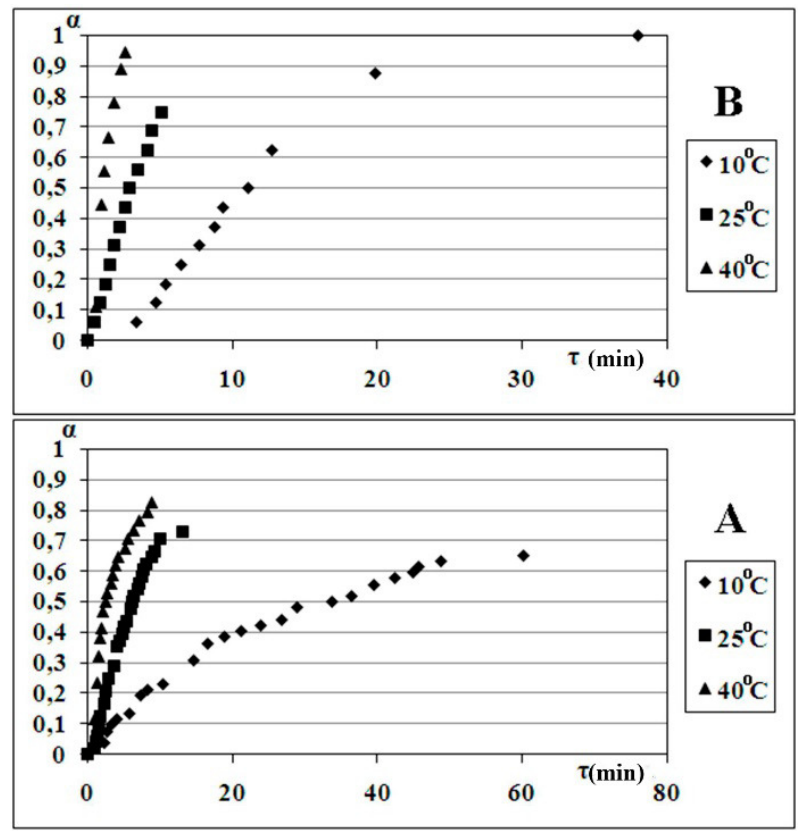

Figure 1.Kinetic curves of the petroleum wax dissolution in the gas condensate $(A)$ and the hexane-cyclohexane-benzene mixture $(B)$ at 10 , 25 and $40^{\circ} \mathrm{C}$, where $\alpha$ is the dissolution degree and $T$ is the time ( $\mathrm{min}$ ).

It is evident that the paraffin dissolution rate in the gas condensate is significantly dependent on temperature, as compared to the composite mixture. The curves geometry indicates that the paraffin dissolution in the studied reagents proceeded from the maximum initial rate. In case of HBCG, this could be explained by a sufficiently high chemical activity of the solvent, and in the case of gas condensate, by the influence of temperature. Rozovsky (1974) showed that such processes are well described by the Erofeev-Kholmogorov equation (Eq.1):

$\alpha=1-e^{-k t^{n}}$

where $\alpha$ is the degree of paraffin dissolution; $k$ is the invariant defining the reaction rate constant; $n$ is the invariant defining the process nature: at $n<1$, it is the diffusion process; at $n>1$, it is the kinetic process; at $n=1$, it is the first order reaction, and the chemical reaction rate is comparable with the diffusion rate.

The dissolution rate constants were found by the Sakovitch formula (Eq.2):

$$
K=n k^{\frac{1}{n}}
$$


To characterize the rate of the first-order reaction, together with the rate constant, we used the half-life value. This value does not depend on the initial concentration of the source substance and is described by Eq.3 (Delmon, 1972):

$\tau_{\frac{1}{2}}=\frac{\ln 2}{K}$

According to the obtained experimental data, the logarithmic anamorphoses of the kinetic curves were plotted in coordinates $\lg [\lg (1-$ $\alpha)]-\lg \tau$ (Figure 2). Parameter $\mathrm{n}$, defined as the trend line slope ratio, allows establishing the order of reaction and the rate-controlling step of paraffin dissolution in the $\mathrm{HC}$ systems under study. The rectification of the experimental curves in a wide range of time indicates a fair choice of the equation to describe the kinetics of dissolution.

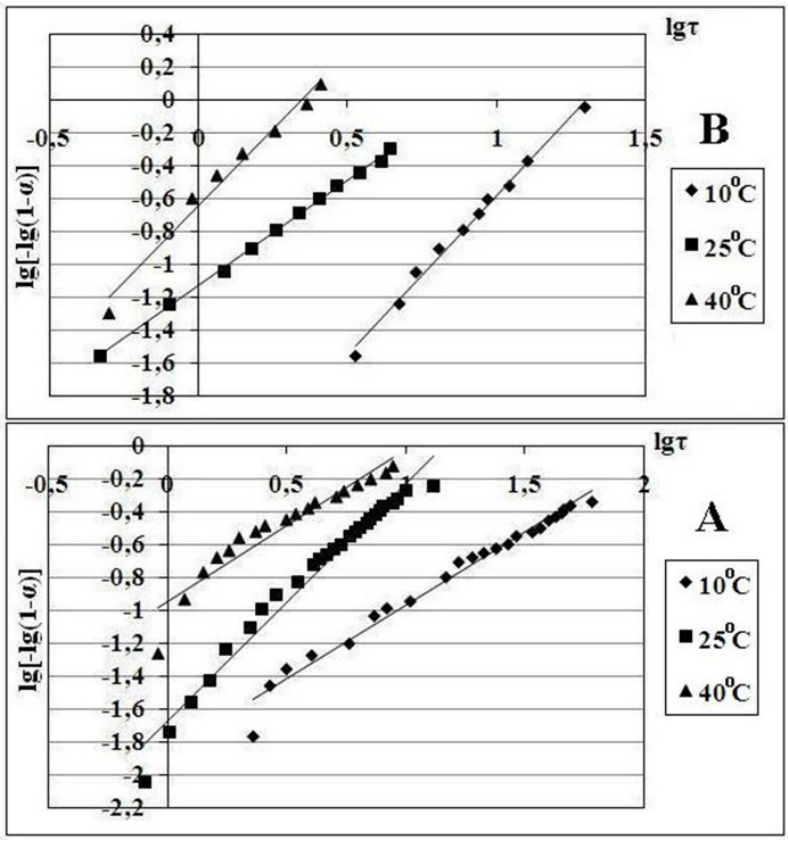

Figure 2.Logarithmic anamorphoses of the kinetic curves for petroleum wax dissolution in the gas condensate $(A)$ and hexane-cyclohexanebenzene mixture $(B)$ at 10,25 and $40^{\circ} \mathrm{C}$.

The kinetic parameters of the paraffin dissolution in the $\mathrm{HC}$ systems, determined by Equations 1, 2 and 3, are given in Table 1.

Table 1 shows that the process of paraffin destruction in the gas condensate at $10^{\circ} \mathrm{C}$ is diffusion controlled $(n<1)$, but when heated to $25^{\circ} \mathrm{C}$ or above, the process shifts to the kinetic model $(n \geq 1)$. In the hexane-cyclohexane-benzene mixture, the process proceeds in the kinetic area $(n>1)$ at different temperatures. The paraffin destruction is most likely to take place in the ternary composite, as the process is characterized by a low value of $\tau_{\frac{1}{2}}$ and an efficient energy of activation (34.6 kJ/mol), while in hexane the energy of paraffin destruction activation is $125.2 \mathrm{~kJ} / \mathrm{mol}$ (Ivanova, 2014). In the gas condensate and in the hexane-benzene mixture, the activation energy has intermediate values: 106.9 and $90.3 \mathrm{~kJ} / \mathrm{mol}$ respectively. The obtained results agree with the findings of Ivanova et al. (2014), where it was found that the dissolution rate constants for the oilfield paraffin type ARPD in the ternary solvent is an order of magnitude greater, as compared to the aliphatic systems, and the process is characterized by a lower effective energy of activation. The studies of paraffin destruction kinetics at higher temperatures made it possible to establish the dependence of logarithm of the dissolution rate constant on the value of the reciprocal temperature (Figure 3).

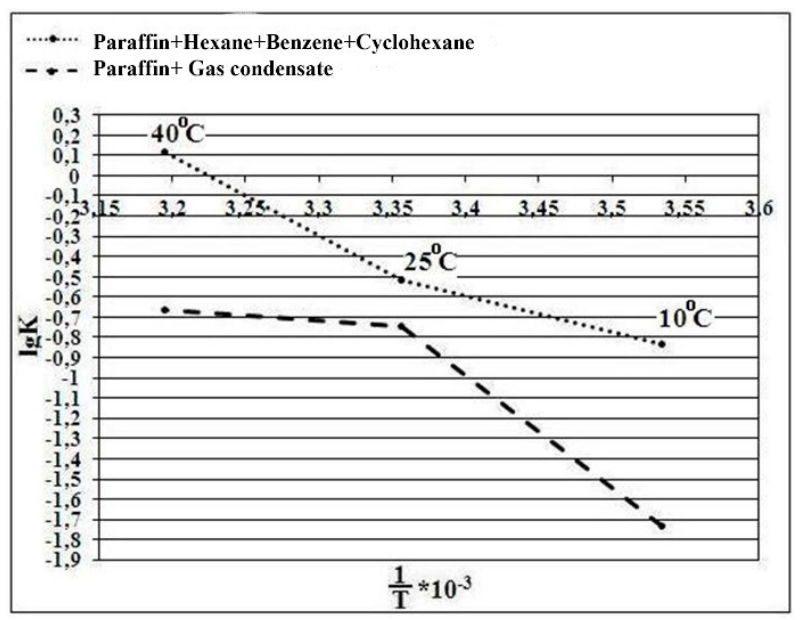

Figure 3.Dependence of the dissolution rate constants $K$ in the gas condensate and the hexane-cyclohexane-benzene mixture on 1/T

It can be seen that for the models under study, the experimental data on the graph in coordinates $\lg K-1 /$ Tare placed on the fractured lines, indicating the deviation from the temperature dependence of the dissolution rate constants in these systems on the Arrhenius equation. This can be explained by the fact that the measured rate constant refers to more than one stage of the reaction. 
Thus, based on the kinetic studies, the composite solvent, consisting of aliphatic, aromatic and naphthenic $\mathrm{HC}$, can be recommended for the removal of paraffin deposits, since in this solvent, the dissolution rate constant has maximum values and the process of paraffin destruction is characterized by the minimum value of effective activation energy.

The influence of the solvent chemical nature on the paraffin crystals morphology was examined by scanning electron microscopy. The microphotographs of the paraffin samples, treated with the studied solvents, are shown in Figures 4 and 5.

According to the microscopy data, the petroleum paraffin (Ivanova et al., 2015) has a dense thin-layered structure; the distance between the layers is $7-12 \mathrm{~nm}$; the thickness of the layers is $25-28.4 \mathrm{~nm}$. In aliphatic solvents, paraffin has a predominantly monolithic structure: in the gas condensate (Figure 4) the thickness of the layer reaches $76.9 \mathrm{~nm}$ and the distance between layers $163 \mathrm{~nm}$, in hexane (Ivanova et al., 2015) these parameters are $44.2 \mathrm{~nm}$ and 20.6 $\mathrm{nm}$, respectively. Hence the process of paraffin dissolution in aliphatic solvents can be characterized by the highest values of effective activation energy. After the treatment with an aliphatic-aromatic solvent (Ivanova et al., 2015), the paraffin crystal formed a large number of cracks, whose width varies from 87 to $573 \mathrm{~nm}$. In the ternary composite (Figure 5), the layer thickness is $57.6 \mathrm{~nm}$, and the distance between layers varies from 46.5 to $427 \mathrm{~nm}$. In this case, the pores are clearly visible on the crystal surface. The pores have 24-29.3 nm in diameter, and the distance between them is from 32.5 to $33.9 \mathrm{~nm}$.

The specified structural features adequately correlate with the kinetic studies and together show the effects of the solvent on the morphological and kinetic parameters of the wax samples dissolution: in the series of aliphaticnaphthenic-aromatic $\rightarrow$ aliphatic-aromatic $\rightarrow$ aliphatic solvents the reagents' effectiveness for the paraffin removal is reduced. Therefore, a composite solvent, consisting of aliphatic, aromatic and naphthenic $\mathrm{HC}$ should be recommended for the paraffin deposits removal, as in this solvent the paraffin obtains a porous structure and the paraffin destruction proceeds at a high speed and with a low activation energy.

It should be noted, however, that when selecting a solvent to remove paraffin deposits in the conditions of low climatic temperatures and permafrost, it is necessary to take into account the temperature of paraffin crystallization in potentially effective solvents. Thus, Ivanovaet al. (2015) found that the temperature of petroleum and oilfield paraffin crystallization in the aliphaticnaphthenic-aromatic solvents has maximum values, as compared to the aliphatic-aromatic solvents. In the gas condensate (Ivanova et al., 2015) which is currently used in the Irelyakhskoe field to clean the oil extraction equipment from paraffin deposits, the petroleum paraffin crystallites appear at $30.1^{\circ} \mathrm{C}$, and when the aromatic components are added, the crystallization temperature decreases to $24.1^{\circ} \mathrm{C}$. For the field of paraffin, these temperatures are 21.8 and $9.1^{\circ} \mathrm{C}$, respectively. The findings testify in favor of the use of aliphatic-aromatic reagents in the permafrost conditions.

\section{CONCLUSIONS:}

This study confirmed that the solvent chemical nature influences the morphological and kinetic parameters of the paraffin dissolution. The kinetic and morphological studies, as well as the comparison with the findings of Ivanova et al. (2014) and Ivanova et al. (2015), showed that the use of gas condensate to clean the oil extraction equipment from paraffin is less effective. A better solution for this purpose would be the aliphaticaromatic-naphthenic solvent. Also, the composite binary aliphatic-aromatic solvents can be recommended to remove the paraffin deposits generated during oil-field development in the permafrost conditions.

\section{ACKNOWLEDGMENTS:}

This work was supported by the Ministry of Education and Science of Russia within the frameworks of the State Assignment Project Organization of Research Activities, No.1896.

\section{REFERENCES:}

1. Delmon, B. Kinetics of heterogeneous reactions. Mir: Moscow, 1972.

2. Dolomatov, M. Yu.; Telin, A. G.; Ezhov, M.B. Physical and chemical foundations of the targeted selection of solvents for asphaltene-resin substances. Central Research Institute of Information and Technical-Economic Studies of Oil Refining and Petrochemical Industry: Moscow, 1991.

3. Glushchenko, V. N.; Silin, M. A.; Gerin, 
Yu. G. Oilfield Chemistry, vols.1-5. Nauka: Moscow, 2009.

4. Ibragimov, N. G.; Tronov, V. P.; Guskova, I.A.. Theory and practice of applying methods to combat organic deposits in mature oilfields. Nephtyanoe Khozyaistvo: Moscow, 2010.

5. Ivanova, I.K. Fundamentalnye issledovaniya. 2014, 11(5), 1028-1031.

6. Ivanova, I. K.; Kalacheva, L. P.; Shits, E. Yu. Rus. J. Appl. Chem. 2014, 87 (4), 429-432.

7. Ivanova, I. K., Koryakina, V. V., and Semenov, M. E. Rus. J. Appl. Chem. 2015. 88 (8), 1326-1333.

8. Kamenshchikov, F. A. Removal of asphaltene-resin-paraffin deposits with solvents. NIC Regular and Chaotic Dynamics, Izhevsk Institute of Computer Studies: Moscow, Izhevsk, 2008.

9. Khisamutdinov, N. I.; Ibragimov, G. Z.; Kobyakov, N. I. Practice of rehabilitation and productivity control of the production wells and the injection wells]. In: Survey Information. Series on Technique and technology of oil production and oil field development. All-Russian Research
Institute of Organization, Management and Economics of the Oil and Gas Industry: Moscow, 1990.

10. Klinger, V. G.. Methodical guide to measurement results processing. Kalinin Polytechnical Institute: Tver, 1972.

11. Ragulin, V. V.;Smolyanets, E.F.;Mikhailov, A. G. NephtepromyslovoeDelo. 2001, 7, 23.

12. Rozovsky, A. Ya. Kinetics of topochemical reactions. Chemistry: Moscow, 1974.

13. Russian National Standard GOST 2368389. Petroleum paraffin waxes: Specifications. Moscow: StandartInform, 2007. gostexpert.ru/gost/getDoc/33653, accessed June 2017.

14. Savinykh, Yu. A.; Grachev, S. I.; Ganyaev, V. P.; Muzipov, Kh. N. Methods to combat paraffin deposits in oil wells. Titul Publishing House: Tyumen, 2007.

15. Atkinson, P.W.; Fuller, R.J.; Vickery, J.A.; Conway, G. J.; Tallowins, J. R.; Smith, R. E.; Hayson, K. A.; Ings, T. C.; Brown, V.K. J. Appl. Ecol, 2005, 42, 932. 
Table 1. Rates constants $\tau_{\frac{1}{2}}$ and energy for activation of paraffin dissolution in the gas condensate and $H B C G$.

\begin{tabular}{c|c|c|c|c|c}
\hline Sample & $\mathbf{T}\left({ }^{\circ} \mathbf{C}\right)$ & $\mathbf{N}$ & $\mathbf{K}\left(\mathbf{m i n}^{-1}\right)$ & $\tau_{\frac{1}{2}}(\mathbf{m i n})$ & $\mathbf{E a}(\mathbf{k J} / \mathbf{m o l})$ \\
\hline Paraffin + Gas & 10 & $0.89 \pm 0.12$ & $1.84^{*} 10^{-2}$ & 37.67 & 106.9 \\
condensate & 25 & $1.44 \pm 0.21$ & $1.81^{*} 10^{-1}$ & 3.83 & \\
Paraffin + Hexane & 40 & $0.93 \pm 0.17$ & $2.18^{*} 10^{-1}$ & 3.18 & \\
+ Benzene + & 25 & $1.92 \pm 0.09$ & $1.47^{*} 10^{-1}$ & - & \\
Cyclohexane & 40 & $1.25 \pm 0.15$ & $3.08^{*} 10^{-1}$ & 2.25 & 34.6 \\
$(1: 1: 1)$ & & $1.86 \pm 0.15$ & 1.32 & - & \\
\hline
\end{tabular}

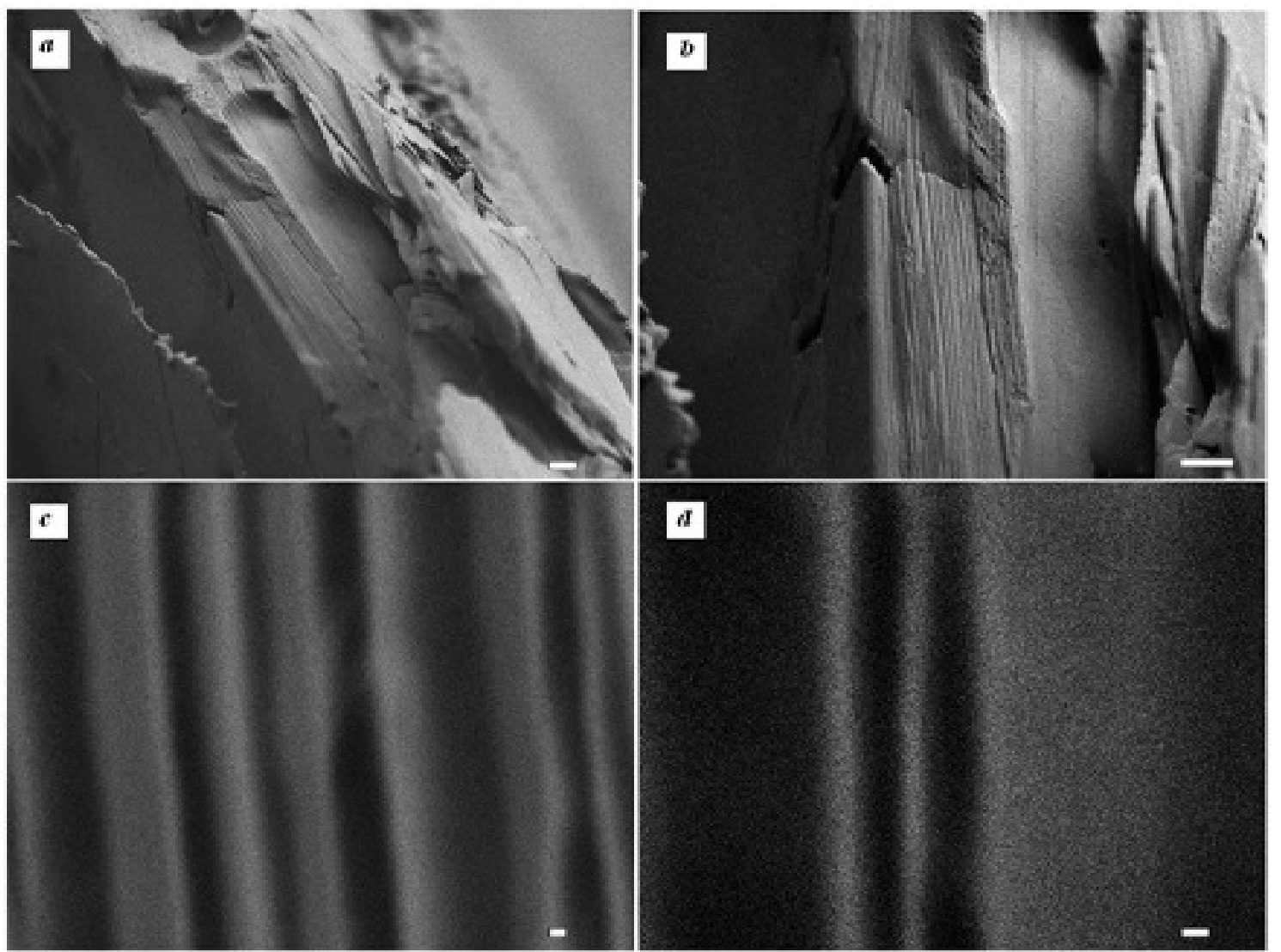

Figure 4.Microphotographs of the crude oil paraffin B2 sample treated with the gas condensate; scale leg: $a, b-10 \mu \mathrm{m} ; c, d-100 \mathrm{~nm}$ 

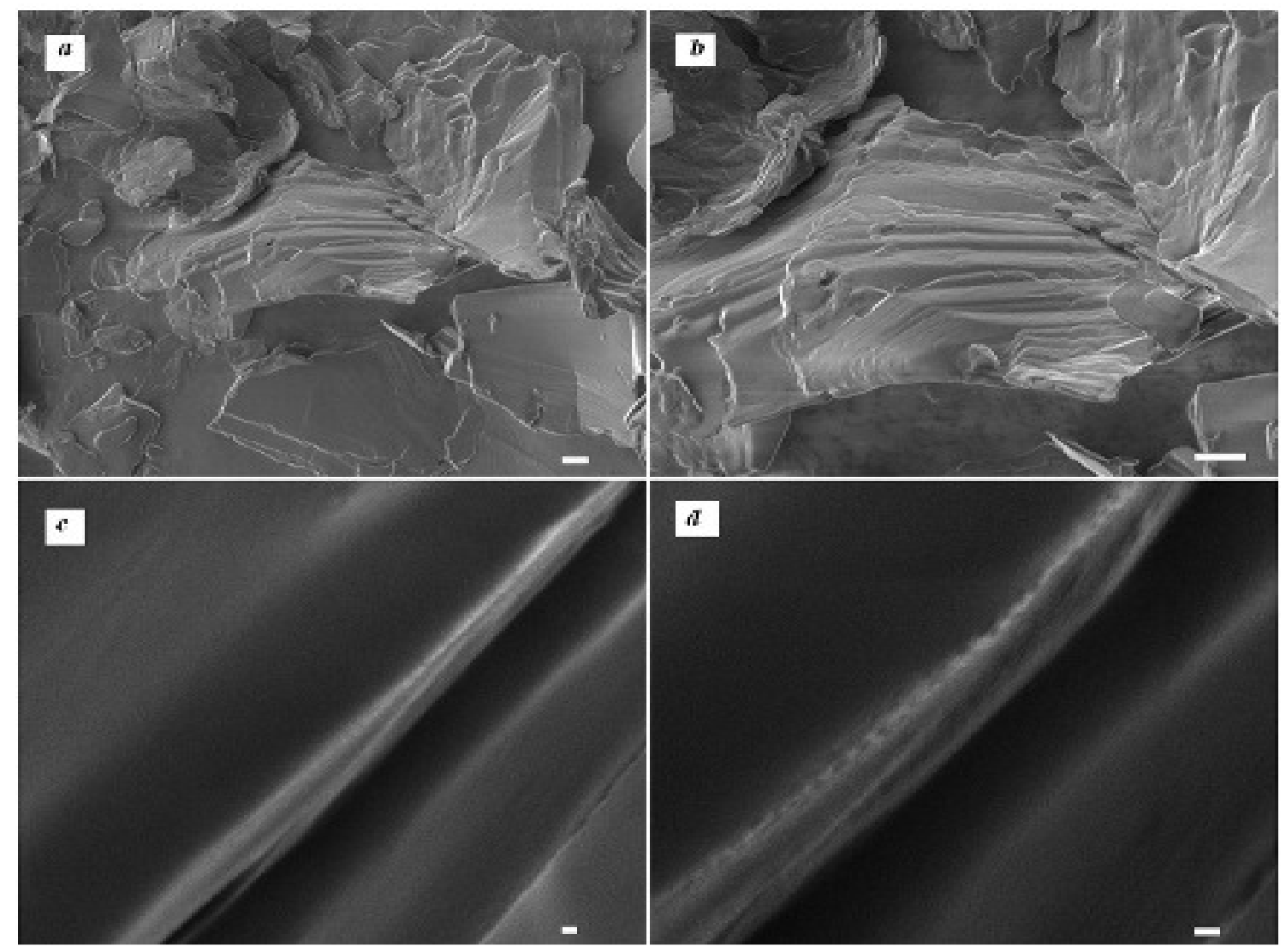

Figure 5.Microphotographs of the crude oil paraffin B2 sample treated with the hexane-benzenecyclohexane mixture; scale leg: $a, b-10 \mu \mathrm{m}$; c, $d-100 \mathrm{~nm}$

PERIÓDICO TCHÊ QUÍMICA•www.periodico.tchequimica.com• Vol. 15 N. 30.

•ISSN 1806-0374 (impresso) • ISSN 1806-9827 (CD-ROM) • ISSN 2179-0302 (meio eletrônico) (C) 2018. Porto Alegre, RS. Brasil

The Periódico Tchê Química (ISSN: 1806-0374; 2179-0302) is an open-access journal since 2004. Journal DOI: 10.52571/PTQ. http://www.tchequimica.com. This text was introduced in this file in 2021 for compliance reasons.

(c) The Author(s)

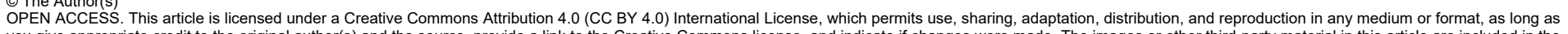
you give appropriate credit to the original author(s) and the source, provide a link to the Creative Commons license, and indicate if changes were made. The images or other third-party material in this article are included in the article 's Creative Commons license unless indicated otherwise in a credit line to the material. If material is not included in the article's Creative Commons license and your intended use is not permitted by statutory regulation or exceeds the permitted use, you will need to obtain permission directly from the copyright holder. To view a copy of this license, visit http://creativecommons.org/licenses/by/4.0/. 